\title{
A RUA COMO ESTILO DE VIDA: PRÁTICAS COTIDIANAS NA OCUPAÇÃO DO CENTRO DE PORTO ALEGRE POR CAMELÔS.
}

\author{
Rosana Pinheiro Machado \\ Ana Luiza Carvalho da Rocha (Orientação)
}

\section{Introdução}

Este pesquisa é fruto de uma etnografia que teve início no ano de 1999, quando cursava o segundo semestre de Ciências Sociais e iniciava-me como pesquisadora de iniciação científica/FAPERGS no Projeto Banco de Imagens e Efeitos Visuais, PPGAS/UFRGS, coordenado pelas Profas. Dras. Cornelia Eckert e Ana Luiza Carvalho da Rocha. Durante esses três anos, desenvolvi esse estudo no âmbito da Antropologia Urbana e Visual e dentro das mais variadas disciplinas oferecidas pelo Curso de Ciências Sociais que exigiam trabalhos de campo e/ou monografias.

O trabalho que segue tem por objetivo apresentar a ocupação social do Centro de Porto Alegre por vendedores de rua (camelôs). Na primeira parte segunda, faço uma reflexão metodológica acerca de meu trabalho de campo com o grupo estudado. Trata-se de uma análise das possibilidades e dos limites da investigação etnográfica no meio urbano, apreendida num processo de iniciação ao trabalho antropológico. A segunda consiste numa retomada histórica, analisando a emergência desse tipo de atividade comercial na cidade; bem como os grupos atuais que compõem o cenário urbano local. Por fim, na última parte, procuro narrar um pouco das práticas cotidianas e das condições de vida camelôs.

\section{1- Questões metodológicas: os desafios do aprendizado etnográfico}

Para atingir o objetivo inicial desta pesquisa, de descobrir quem são e como vivem os camelôs que trabalham na região central de Porto Alegre, passei por um longo processo de aprendizado etnográfico. Comecei a ir a campo no ano de 1999, no início do curso de Ciências Sociais. Na ocasião, pouco sabia sobre como fazer um trabalho de campo. Além disso, não possuía nenhum referencial teórico, somente uma grande curiosidade de entender aquele universo. 
Na primeira ida a campo, eu ficava olhando tudo de fora, sentada na sarjeta e anotando tudo o que ocorria. Aos poucos, fui me aproximando dos vendedores, conversando e perdendo o constrangimento. Escrevi na segunda visita que realizei: "Os camelôs, ao contrário do que eu pensava, são pessoas gentis e educadas." Naquele período, de iniciação ao método etnográfico, eu não percebia o preconceito presente em meus apontamentos que, naquele momento, começava a se desfazer.

No primeiro ano de pesquisa, eu estranhava ficar na rua. Para mim, o espaço público era um lugar de passagem, de anonimato e de impessoalidade. Era um verdadeiro choque ficar parada durante horas, no meio das ruas do Centro, onde transitavam tantas pessoas. Sentia-me fora do fluxo das pessoas que tão rapidamente passavam por lá. Estranhava mais ainda ficar sentada em cadeiras de praia, em plena da sarjeta. Naturalmente, isso foi passando, justamente quando comecei a cada vez mais me familiarizar com os camelôs. Para Da Matta (1978: 04) o etnólogo precisa se familiarizar com o que lhe é exótico e tornar exótico o que lhe é familiar. No meu caso, por estudar um grupo urbano que vive na mesma cidade que eu, necessitei estranhar a região central de Porto Alegre que me era muito familiar e bastante presente na minha vida. Por outro lado, tive que me familiarizar com um grupo que, apesar de viver na mesma cidade que eu, era completamente diferente de mim em seus estilos de vida e visões de mundo.

Eckert e Rocha (2001) analisam a "etnografia de rua" enquanto uma técnica de trabalho de campo antropológico. Segundo as autoras, o pesquisador, para conhecer a cidade, necessita percorrer ruas e pensar a si mesmo na paisagem urbana. Assim, conhecer uma cidade não é apenas conhecer seus habitantes e estar junto a eles, mas sim, pensar sobre a sua própria experiência em relação à experiência do Outro no mesmo espaço urbano.

O início da minha experiência de campo, obrigou-me a reconsiderar as noções que eu trazia sobre o espaço da rua e as noções daqueles que faziam da rua um lugar onde construir seus mundos, fazendo-me refletir não só sobre os hábitos, fazeres e saberes dos camelôs, mas também sobre bagagem cultural que eu levava comigo quando ia a campo.

Afinal, como diz Da Matta (1978:03), a etnografia é uma ponte entre dois universos ou sub universos e tal encontro "é permeado por emoções, temperamentos, fobias e outros ingredientes das pessoas no contato humano". 
Segundo a orientação de uma "etnografia de rua", sempre trabalhei em campo de duas maneiras: sentada junto aos camelôs e caminhando incessantemente pelos espaços que os rodeiam. Estar caminhando entre eles, fez-me aprender a desenvolver um olhar para captar várias cenas que se fazem e se desfazem em questões de segundos. Aos poucos, comecei a apreender, diante de toda a instantaneidade e anonimato das ruas, alguns personagens e cenas que começavam a se repetir. Assim, familiarizar-me, aos poucos, com os camelôs e com o espaço em que trabalham. Conforme dizem Eckert e Rocha (2001), passei a perceber este território como se ele fosse minha morada, um lugar de intimidade, repouso e acomodação afetiva.

A importância dos recursos audiovisuais foi crucial, mais especificadamente da máquina fotográfica. Esse instrumento foi meu principal aliado na busca dos fragmentos aparentemente dispersos das cenas múltiplas, que acontecem no camelódromo da Praça XV. A fotografia serviu "como um ritual de sedução e conquista da atenção do Outro" (ECKERT E ROCHA, 2001), como um convite a uma aproximação mais duradoura com os camelôs.

Os vendedores estão bastante acostumados a serem fotografados pela mídia. Esse fato, causou-me os melhores e os piores momentos em campo. Os melhores foram aqueles em que todos me pediam que os fotografassem, mostrando-me suas bancas, suas famílias e, sorridentes, aproximavam-se de mim. Revelando as imagens, eu começava a desenvolver um novo olhar sobre o grupo. No enquadre de uma foto, encontrava uma estética das bancas que me surpreendia e me mostrava um mundo novo. Além disso, retornar com as fotos e devolvêlas para os camelôs criava um laço de reciprocidade: enquanto eles me ajudavam na pesquisa, ganhavam de volta as cópias das fotos, que não acreditavam receber de volta. Deste modo, passei a ser vista por todos sempre como a guria da foto.

Entretanto, a fotografia também foi motivo de situações conflituosas pelas quais passei. Muitas vezes, tive que negociar com camelôs, explicando-lhes que eu não era da imprensa jornalística e que não queria denunciá-los. Demorou bastante tempo para eles adquirirem confiança em mim e perceberem que eu apenas queria conhecer a vida deles. Mas ainda me deparo com esse tipo de problemas. No final do ano de 2002, pedi licença para fotografar um camelô que estava jogando cartas. A agressividade dele foi tanta que, pela primeira vez, senti medo da reação de um vendedor. Ele alegava: “quer me enganar que só 
quer saber como a gente vive? Acha que eu sou trouxa?". Naquele momento, os camelôs que me conheciam, iniciaram uma discussão com ele em minha defesa, mas ele continuou irredutível.

A etnografia com os camelôs também mudou meu olhar sobre o Centro de Porto Alegre. As camadas médias porto-alegrenses têm abandonado essa região e se fechado cada vez mais em seus próprios bairros e shoppings centers. Frequientemente, a mídia reproduz o discurso de que há um Centro degradado, que necessita ser "revitalizado". A partir do trabalho de campo, descobri uma nova cidade, um novo bairro. Afinal, comecei a enxergar esse bairro como um lugar vivo, colorido e belo por sua diversidade cultural. Ao conhecer os camelôs e estudar a história do Centro, passei a ver este território como um "objeto temporal, lugar de trajetos e percursos sobrepostos, urdidos numa trama de ações cotidianas" (ECKERT E ROCHA, 2001). O Centro, para mim, passou a ser um lugar não de decadência urbana, mas sim um bairro construído no tempo da memória de homens e mulheres que deixaram e deixam seus traços por lá.

A pesquisa de campo foi sempre uma troca. Para eles, não existe a lógica de que eu estava ali somente para saber como vivem. $\mathrm{O}$ fato de eu estar com eles, passava por uma interpretação da suas partes que resultava na ressignificação de meu papel ali enquanto aprendiz de antropóloga. Ou seja, meus informantes não me tratavam como uma pesquisadora: eu era uma espécie de amiga. Por isso, assim que eu chegava, contavam-me suas vidas e muitas vezes tive problemas em saber até que ponto eu podia escrever o que me contavam, visto que muito do que sei, foi dito para a amiga e não para a pesquisadora. Penso que isso ocorria por eu ficar observando-os o tempo todo, o que lhes causavam verdadeiro estranhamento. Para eles, provavelmente não havia sentido em uma pessoa estar parada, enquanto eles trabalham num ritmo tão acelerado. Por isso, a cada visita, eles me atribuíam algum significado: ora eu era a desculpa para eles darem uma fugida do camelódromo, ora era a amiga para quem desabafavam suas angústias. Entretanto, muitas vezes eu não tinha nenhuma destas funções e eles me colocavam diretamente no trabalho: davam-me as joaninhas para eu ir alcançando para eles, pediam que segurasse os fios da lona que armam em dia de chuva, etc. 
Obviamente que, para ser aceita no grupo, passei por diversas provações, verdadeiros ritos de passagem. ${ }^{1}$ Muitas vezes, em situações em que a fiscalização chegava e o ambiente ficava tenso, tinha que agir como um deles. Em outras situações, testavam-me para ver se eu iria mesmo voltar com as fotos que tinha prometido. Uma vez, dois jovens camelôs simularam uma briga para ver se eu ficava com medo. Passar por esses fatos, tornou-me uma "pessoa de fé" (alguém em quem eles podem confiar). A situação de maior reconhecimento pela qual passei foi quando uma vendedora me deixou cuidando de sua banca. De acordo com o que demostrarei nos capítulos seguintes, este é uma ato de extrema confiança.

De todos camelôs que conheci, a pessoa que mais me recebeu, e que se tornou minha informante chave, foi a vendedora Ângela, de 36 anos. Foi através dela que comecei a "entrar no mundo dos camelôs" a partir de uma relação de alteridade e empatia recíproca (Da Matta, 1978:10). Ela sempre me falava de seu pai, dizendo que ele era o camelô mais antigo da Praça XV. Durante mais de um ano, tentei me aproximar dele e ele, simplesmente, ignoravame. Conquistá-lo passou a ser meu maior desafio. Uma vez, eu estava na banca com Ângela e seu pai estava junto. Naquele momento, ocorreu um assalto em uma banca e se formou um grande tumulto, quando os camelôs pegaram o assaltante e começaram a brigar com o mesmo. Eu não sabia o que fazer: se fugia da briga ou se entrava no tumulto. $O$ pai da Ângela, seu Ney, me pegou pelo braço e disse: "Vem comigo, guria! Não quer nos conhecer?" Não tive escolha, fui para o meio da briga compartilhar das fofocas que corriam por ali.

Geertz (1989:186) conta que, durante muito tempo, em sua pesquisa de campo na sociedade balinesa, não era visto pelos nativos. Durante uma briga de galos a que assistia junto com sua mulher, chegou a polícia e todos fugiram, inclusive ele, como se fosse um nativo. Este fato fez com ele passasse a ser reconhecido pela população balinesa, visto que ele, enquanto pesquisador, não precisaria ter fugido. $\mathrm{O}$ autor chama atenção para esse fato, pois salienta o quanto certas situações sociais são chaves para a inserção de um pesquisador num determinado campo. Aquele momento foi crucial para sua entrada em campo, além de poder compartilhar com os nativos de uma efervescência social embutida de significados e emoções, que delimitavam os contornos de sua identidade social.

1 Estas situações Da Matta (1978:03) chama de aspectos anedóticos e românticos da etnografia. 
Quando entrei no tumulto com os camelôs, vivi uma situação que me lembrou Geertz. Afinal, naquele momento eu comecei a ser vista por todos, e principalmente por Ney. Quando “olhei" para mim, estava fofocando com um entusiasmo inédito. As pessoas me perguntavam como o ladrão tinha sido pegado e eu ia repassando as informações com detalhes de pessoa para pessoa. Acredito que este dia foi um divisor de águas no meu campo, seja no modo de eu agir com eles, seja na maneira como eles passaram a me ver.

No primeiro ano de campo, centrei o estudo nas práticas cotidianas de Ângela e seus vizinhos de banca. Graças a ela, conheci o Pio (vendedor de 37 anos) e sua família. Ela ia-me apresentando os vendedores que constituíam sua rede de relações cotidianas. Já mais habituada ao campo, resolvi conhecer outras pessoas do camelódromo que não fossem do círculo de Ângela. Desse modo, conheci Léia (36 anos), Dona Maria (66 anos), Seu Anibal (52 anos), Dona Diva (60 anos), entre outros. Estes novos informantes me revelaram um novo lado do camelódromo: um lugar constituído por inúmeras redes internas de conflito e solidariedade. Além disso, suas vidas me mostraram as dificuldades do viver na rua.

Durante a jornada e todos os encontros, fui escrevendo diários de campo, analisando as imagens que produzia, entrevistando vendedores e recolhendo informações de depoimentos espontâneos. Além disso, fui criando um banco de dados referente a todas as matéria publicadas nos jornais gaúchos (Zero Hora, Correio do Povo e Diário Gaúcho) sobre camelôs e mercado informal. Procurei, enfim, unir estes dados às teorias antropológicas que pudessem me ajudar a entender melhor o que denomino de "vida de camelô".

Atualmente, quando estou em campo, sempre conheço pessoas e situações novas. Ainda passo por momentos de estranhamento que são acomodados numa dialética de repulsa e familiarização. Um destes atos de estranhamento ocorreu quando assisti, durante uma manhã inteira, a venda de remédios abortivos. Sempre soube desse tipo de venda irregular. No entanto, quando eu estava compartilhando o momento da negociação, senti um desconforto inédito. A maneira como eles recomendavam a interrupção da gravidez e a quantidade de pessoas que compravam o remédio, entraram em choque diretamente com minhas noções sobre corpo e saúde.

A partir desse dia, entrei em contato direto com uma série de questões referentes ao contrabando e à compra e venda de produtos roubados. Esse fato me fez amadurecer em campo, no momento em que eu tinha que interagir com eles usando táticas que negociavam 
com meus valores pessoais e sociais. Deste então, passei a dosar os extremos na análise do grupo: nem glorificá-los, nem descriminá-los. Apenas compreendê-los.

\section{Contextualizando o objeto: vendedores de rua - "onde termina o mundo"}

No ano de $1989^{2}$, a Prefeitura Municipal, através da Secretaria de Indústria e Comércio (SMIC), cadastrou a maioria dos vendedores de rua existentes na região central de Porto Alegre e criou - tentando resolver um problema histórico -, o Camelódromo da Praça $X V$. Essa regulamentação obedecia aos seguintes critérios: que os vendedores comercializassem mercadorias lícitas e que estivessem na rua há bastante tempo, dando preferência àqueles cujos pais também tivessem sido ambulantes. Foram cadastrados e regularizados um total de 420 vendedores. Nesse processo de legalização, os vendedores da Praça XV de Novembro pediram à Secretaria Municipal que fossem oficialmente chamados de camelôs e que o lugar das bancas se chamasse camelódromo.

A Praça XV possui diversificadas formas de sociabilidade, ou seja, vários grupos coexistem e interagem no mesmo espaço urbano. Além dos camelôs e de outros vendedores de rua, há também os tradicionais freqüentadores da Praça XV e redondezas, que caracterizam o local: boêmios, intelectuais, pregadores religiosos, fotógrafos "lambe-lambe", engraxates, jornaleiros, mendigos, deficientes físicos, moradores de rua, prostitutas. Todos esses atores, aliados a um grande número de pessoas que por lá transitam todos dias, vão desenhando uma ambiência marcada pela forte concentração humana, formando um quadro cotidiano em que milhares de cenas são produzidas e desfeitas, em questão de segundos, aos olhos de quem as observa.

O camelódromo situa-se próximo a pontos tradicionais e turísticos da cidade, tais como o Mercado Público e o Chalé da Praça XV. Para se chegar a estes locais, é preciso desviar de muitos vendedores que anunciam repetidamente seus produtos. A concentração de bancas, produtos e pessoas é tamanha que não se pode contemplar as obras arquitetônicas isoladamente. Trata-se de uma paisagem sobretudo humana e sonora, que se caracteriza pela 
diversidade cultural e pela coexistência de diversos estilos de vida e visões de mundo. Assim, se estamos no Centro, ora nos deparamos com pessoas de camadas médias e altas que fazem das vias apenas um lugar de passagem, ora nos deparamos com grupos populares que se apropriam dos espaços, reinventado o sentido de "vias de passagem" dado para a rua.

O Centro da cidade, mais especificadamente a Praça XV e seus arredores, sempre foi caracterizado pela presença de um grande contingente de vendedores de rua ${ }^{3}$. Porto Alegre emergiu e cresceu graças ao comércio que começou a se instalar a partir do século XVIII, principalmente no Largo da Quitanda (atual Praça da Alfândega). No final deste século, esse logradouro caracterizava-se pela forte presença de escambo e vendas de peixe, fazendo expandir o comércio da cidade. Em 1820, foi construído o prédio dos serviços alfandegários e, por isso, houve uma pressão dos grandes negociantes ${ }^{4}$ locais para retirar da praça as bancas do pequeno comércio, o intuito era melhorar a ambiência e evitar o mau cheiro no entorno. Os governantes decidiram que os vendedores de rua seriam transferidos para a Praça Paraíso (atual Praça XV de Novembro), local este que, desde 1815, já estava predestinado, pelo poder público municipal, para receber a Praça do Peixe.

Desse modo, a Praça Paraíso ${ }^{5}$ consolidou-se sem qualquer urbanização, recebendo quitandeiros, negociantes e moradores, e passou a ser o principal local de comércio de rua da cidade de Porto Alegre. Portanto, a tradição de negociantes e vendedores de rua -bancas irregulares de peixes, frutas, muidezas, etc - nas redondezas da hoje Praça XV de Novembro; é tão antiga quanto a própria praça, ou melhor, este tipo de atividade foi fundante para a sua consolidação na cidade. Nascia ali um verdadeiro locus comercial que se perpetua até hoje com o trabalho dos camelôs, ambulantes e fruteiros. Entretanto, inúmeros planejamentos de retirada desses vendedores se sucederam ao longo da história, desde o século XIX até os dias de hoje.

\footnotetext{
2 A legislação municipal que regularizava os ambulantes antes de 1989, era do ano de 1968, por isso já estava ultrapassada.

3 Ver em anexo: linha do tempo sobre a ocupação comercial do centro de Porto Alegre.

4 Eram 57 ao todo. Entre os quais se destacam: casas de negócios, plantações de trigo, pequenos moinhos, criação de gado, sociedade em iates para navegar na Lagoa dos Patos. (História Ilustrada de Porto Alegre, 1997: 47).

${ }^{5}$ De acordo com os registros municipais da época, antes de receber os quitandeiros do Largo da Quitanda, ou melhor, por volta da primeira década de século XIX, havia no local uma famosa casa de prostituição que se chamava "Casa Paraíso", que originou o popular nome "Praça Paraíso".
} 
A Praça Paraíso sempre foi "sonhada" pelos poderes públicos como um logradouro que significasse o progresso e a modernidade. Para tanto, intervenções públicas aspiravam a ordenar o local, controlando as casas de prostituição, organizando o comércio e retirando o lixo. Assim, com o intuito de eliminar esta ambiência que parecia caótica, em 1844 foi construído o primeiro mercado da cidade na Praça Paraíso. ${ }^{6}$ Contudo, essa obra foi insuficiente e acabou sendo demolida em 1870, quando foi entregue à população um novo Mercado em 1869, de maiores proporções, construído também na Praça Paraíso, porém no alinhamento da Rua Voluntários da Pátria. (FRANCO, 1998: 270). Ele foi inaugurado com o objetivo de oferecer a Porto Alegre uma obra monumental como as das grandes cidades e de acomodar melhor os comerciantes locais. Finalmente, em 1913, foi adicionado mais um andar ao Mercado, consolidando a forma que permanece até hoje.

De 1890 a 1924, houve a consolidação da ordem burguesa na cidade com a renovação urbana e tecnológica que fizeram Porto Alegre viver "o sonho das cidades civilizadas européias". 7 Neste período de política higienista, os pobres são varridos do Centro, numa tentativa de impedir as sociabialidades populares, a promiscuidade e a prostituição (Pesavento, 1991:42). A modernização dos espaços urbanos em Porto Alegre a partir de 1920 instaurou, assim, uma série de práticas moralizadoras, que começaram a se impor diante das sociabilidades públicas:

"Eram campanhas que visavam integrar as classes populares ao universo dos valores burgueses, através da disseminação de novo imaginário de sociedade e de sociabilidades públicas, bem como, legitimar o desenvolvimento de mecanismos de controle deste novo contingente populacional que se dirige às grandes cidades brasileiras na década de 1920” (Monteiro, 1992:273).

\footnotetext{
6 Esta obra ocorreu devido ao espanto do presidente da província, Saturnino de Souza e Oliveira, de que Porto Alegre ainda não tinha um mercado estabelecido, "este fundamental instrumento da vida comunitária." Fala do Presidente da Província relatada pelo cronista Felicíssimo de Azevedo. (FRANCO, 1998: 337).

7 Entre as realizações mais marcantes temos a extinção de becos ( do Mijo, Pecados Mortais, do Leite, etc.) e abertura de ruas que passavam a receber nomes de personalidades notáveis.
} 
Entre as décadas de 1930 a 1950, o cenário urbano de Porto Alegre começou a mudar radicalmente: os arranha-céus verticalizam a paisagem citadina, iniciou-se a abertura de grandes avenidas, que eram verdadeiras "cirurgias urbanas" (Pesanveto,1991). A partir desta época, no Centro de Porto Alegre, as elites viveram o sonho da cidade moderna e civilizada. O Centro, principalmente a Rua da Praia , é o palco do glamour com seus cafés, cinemas e confeitarias. Entretanto é nesse período que começa a inversão da proporção entre as populações rural e urbana. $\mathrm{O}$ número de habitantes das cidades se multiplicam com a explosão demográfica e com a acelerada migração do campo para as grandes metrópoles. Os que migram buscam trabalho e melhores condições de vida. Os recém-chegados, aliados à numerosa população de origem africana pós-abolição, vão formar o grande contingente de pobres e população de baixa renda. Essa população irá configurar o cenário urbano das grandes cidades brasileiras em busca de trabalho e de moradia. ${ }^{8}$ (Velho, 2000).

As reportagens da Revista do Globo das décadas de 1940 e 1950, apontavam como manchete:

\footnotetext{
"Onde começa e termina o mundo: é difícil ganhar a vida no submundo dos cafés, praças e ruas [do centro]".
}

(Revista do Globo, 1944)

A reportagem da mesma revista cujo título "Comércio ambulante: Pitoresco e Abusivo", trazia o seguinte anunciado:

“(...) Em Porto Alegre ele [comércio ambulante] começou em áreas restritas, principalmente das proximidades dos abrigos de bondes, de mercados públicos e outros locais de acesso obrigatório. De alguns anos para cá, esta forma de comércio cresceu de maneira impressionante, não escolhendo mais ruas próprias, nem ramos de venda. A inovação conseguiu mudar mesmo até a paisagem urbana.

8 O processo de industrialização que culminou na década de 1950, foi uma das causas destas conseqüências apontadas por Velho. 
(...) O que não se pode aceitar é que ele exista de forma

desorganizada, tomando por completo as calçadas , com gritarias estridentes, formando um supermercado em vias públicas".

(Revista do Globo, 1958)

A partir dessas reportagens podemos perceber um tom diferenciado no tratamento que a imprensa dispensou às atividades exercidas nas ruas centrais da cidade de Porto Alegre, por meio de expressões do tipo "abusivo, pitoresco, submundo, onde termina o mundo, etc." Essa linguagem aponta que o trabalho de rua era considerado algo fora de lugar, principalmente no que diz respeito à cidade que cresce e se moderniza. Além disso, percebemos, na reportagem de 1958, que há um espanto para com esse contingente que surge e muda a paisagem urbana. Seus hábitos, principalmente a respeito da fala "estridente" e da onipresença nas ruas e calçadas, incomodam àqueles que começam a encarar o ideal de cidade onde as relações sociais são pautadas pela impessoalidade, individualismo e pelo repúdio das relações face to face. (Velho, 2000).

Assim, desde os tempos mais remotos, o Centro de Porto Alegre e a Praça XV de Novembro se caraterizaram pela presença de vendedores de rua, sendo que, atualmente, eles se dividem em vários categorias, entre as quais ${ }^{9}$ :

Camelôs: 420 vendedores - regularizados em 1989 pela Secretaria Municipal de Indústria e Comércio - trabalham em banca fixa no camelódromo da Praça XV e na rua Vigário José Inácio.

Ambulantes: vendedores em situação ilegal. O número pode variar entre 200 e 2.000, dependendo do quadro econômico, da intensidade do controle da fiscalização e da época do ano.

9 Esse tipo de diferenciação entre ambulantes e camelôs é uma convenção municipal para distinguir trabalhadores legalizados e ilegais. Antes de 1989, todos os vendedores de rua eram vendedores ambulantes. 
Vendedores de Alimentos: fruteiros e vendedores de pipoca, cachorro-quente e churrasco - a maioria deles é licenciada pela Secretaria e Indústria e Comércio.

Percebe-se, portanto, que hoje existem - atuando no comércio informal na região central de Porto Alegre - vários grupos e categorias diferenciadas de vendedores de rua. Todos esses atores estão lutando por um espaço que é público e atrai muitas pessoas devido a sua localização favorecida ( perto do Mercado Público, entre ruas importantes e próximo ao terminal de ônibus da Praça Parobé). Mais especificadamente, temos o seguinte universo regularizado na região central da cidade: vendedores de alimentos e 420 bancas de camelôs. Todos eles estão espalhados no espaço compreendido pelas ruas Máua, Dr. Flores, Riachuelo e Caldas Júnior. Esta região, denominada "quadrilátero central", é considerada crítica pelo poder público. Sob hipótese alguma é permitido licenciar mais vendedores nesta área devido a extrema concentração de lojas, de camelôs e de transeuntes. ${ }^{10}$

Os ambulantes estão em situação irregular porque que apareceram após o ano de 1989 (ano da regularização) e, desde então, não houve nenhum recadastramento. Atualmente, são centenas de pessoas que trabalham na ilegalidade, em condições extremamente precárias e sob o risco da chegada da fiscalização. Em geral, atuam sobre as calçadas e vendem miudezas de baixo custo sobre um caixote, necessitando, freqüentemente negociar sua permanência com os agentes da fiscalização municipal. No Centro de Porto Alegre, esse tipo de comércio cresce constantemente. Os espaços tornamse cada vez mais disputados por inúmeros tipos de vendedores que tentam, de qualquer forma, vender alguma coisa. Os ambulantes não querem vender fora do quadrilátero central, nem que para isto tenham que freqüentemente desmontar suas bancas improvisadas sobre um caixote e fugir da fiscalização. Assim, todas as calçadas do perímetro central da cidade estão ocupadas, tornado o local um verdadeiro palco de disputa por metro quadrado.

Além desses vendedores que reivindicam à Prefeitura espaço no Centro da cidade, há também os lojistas que pressionam o poder local para a retirada dos camelôs e ambulantes dessa região, alegando que eles aumentam a violência e a sujeira das suas ruas e avenidas. As

10 De acordo com a entrevista que realizei em abril de 2002, com o então chefe da fiscalização da SMIC, Sr. Sebastião Barbosa, em 1989, quando a Prefeitura regularizou o universo de 420 camelôs, ela fez um "pacto" em que, devido à grande movimentação do quadrilátero central, nenhum vendedor de rua poderia ser mais cadastrado neste espaço. 
lojas do Centro, atualmente, têm diminuído sua clientela devido à concorrência desleal dos camelôs. Afinal, não pagam impostos, aluguéis e funcionários e, portanto, podem oferecer mercadorias a preço muito inferior ao das lojas.

O sindicato dos lojistas (SINDILOJAS), para tentar solucionar o problema, tem apoiado e patrocinado o "Projeto de Revitalização do Centro da Cidade", que tem por objetivo - além de reurbanizar as ruas e praças e recuperar prédios históricos - realocar camelôs em áreas específicas, cabendo ao poder público fiscalizar e controlar os ambulantes e camelôs, e aos lojistas, financiar parte das obras de recuperação.

Nos últimos cinco anos, os lojistas têm pressionado a SMIC para atuar com firmeza no controle dos ambulantes ilegais. Quanto aos legalizados, os camelôs, o SINDILOJAS pediu que eles fossem reorganizados em uma única área. Deste modo, em 5 de janeiro de 2000, os camelôs foram concentrados no camelódromo da Praça XV e na Rua Vigário José Inácio. Antes dessa data, estes vendedores ocupavam também a rua Marechal Floriano - local onde ainda realizei trabalho de campo em 1999, antes de ser extinto enquanto camelódromo.

Em janeiro de 2002, a imprensa local noticiou, para julho do mesmo ano, a inauguração do um shopping popular, que reuniria camelôs e ambulantes ${ }^{11}$. Poucos dias após o anúncio, o então Prefeito Tarso Genro, bastante otimista, já anunciava um segundo shopping popular. A proposta consistia em destinar ao shopping um antigo prédio da Rua Voluntários da Pátria. Durante dois anos, os camelôs e ambulantes receberiam benefícios para ficarem no local e, a partir de então, quando estivessem bem estabelecidos, começariam a pagar aluguel e impostos. Entretanto, durante o mês de janeiro, os camelôs regularizados da Praça XV começaram a se manifestar contra o projeto. Alegavam que se estavam na rua é porque não queriam estar em um shopping, além disso; se fossem transferidos seus lugares ficariam livres e os ambulantes tomariam conta. Assim, em março de 2002, 300 dos 420 camelôs regularizados promoveram um protesto, no qual eu estava presente, pedindo que fosse construída uma cobertura no camelódromo, pois de lá não sairiam. E assim um camelô me dizia:

11 Percebemos que esta obra tem os mesmos fins que o antigo projeto da construção do Mercado Público. Ou seja, retirar os vendedores de rua que causam a desordem do local. 
"Imagina que eu vou trabalhar fechado, de sapatinho e tudo.... querem nos

infurnar num buraco em que ninguém vai aparecer, imagina só, se aqui, onde passa toda esta gente, a gente já não vende nada, imagina lá.... Se eu sou camelô, é porque eu sou camelô, não quero ser microempresário".

Seu colega de banca concordava:

"Olha só, guria, estou aqui há 30 anos, se eu sair do meu ponto, outros vão aparecer e pegar o meu lugar, como sempre aconteceu, sempre vai ter gente para vender na rua".

As considerações acima servem para pensar os projetos de melhoria do Centro como um todo (desde a construção do Mercado Público até o atual projeto de um shopping popular). Ou seja, desde a fundação de Porto Alegre, podemos observar que estas idéias vêmse difundindo e acabam em políticas públicas que têm como meta a organização do Centro, através do controle dos vendedores de rua informais e/ou ilegais. Logo, o discurso do Projeto de Revitalização não é novo quando alega a necessidade de limpar e modernizar o Centro, de controlar os ambulantes e de trazer novamente para o local as camadas médias e as elites porto-alegrenses. Embora se observe que, ao contrário destas intenções, os vendedores de rua, em suas formas populares de ocupação do espaço, tem sido - ontem e hoje - uma das mais tradicionais presenças na região central da cidade e na Praça XV de Novembro.

\section{2. “Um dom especial” - as práticas urbanas entre camelôs.}

A intenção desta análise é desvendar o universo simbólico da vida cotidiana dos camelôs situados na Praça XV do Centro de Porto Alegre. Procurarei fazer um percurso que mostre quem são e como vivem os trabalhadores de rua que habitam as calçadas da região central da cidade. Ao fazer isso, estou narrando não só suas vidas e seus pequenos dramas diários, mas também contando a minha trajetória de descobertas sobre as formas de vida social existentes nesse grupo urbano. As relações sociais descritas aqui são fatos que vivi e interagi com os vendedores ao longo de meu processo de trabalho de campo. São constatações e vivências etnográficas indispensáveis à compreensão antropológica do que denomino "vida de camelô". 


\section{a) A Jornada de Trabalho}

Porto Alegre, 5 de Novembro de 2001: Amanhece em Porto Alegre e o sol nem chegou a raiar no chão da Praça X.V. O superfície deste lugar está toda marcada e dividida em números sobre os quais a banca será montada. Aos poucos, começa a chegar um que outro. A Praça se toma de tom, som e cor. Passam as pessoas; o sol e chuva; o calor e frio. Anoitece $e$ as coisas se acalmam. Tudo é desmontado e, assim, aguardamos o próximo dia...

Entre as 7 e 8 horas da manhã, os camelôs começam a chegar à Praça XV de Novembro. As bancas são móveis, porém passam a noite fechadas na rua com as mercadorias dentro. Quando eles chegam, geralmente trazem de casa, ou de algum depósito existente por perto, mais mercadorias em grandes sacolas do Paraguai.

O dia inicia quando o vendedor começa a abrir a banca e arrumá-la. Ângela (uma das poucas vendedoras que mora no Centro e tem seu depósito na própria casa) chega por volta das sete da manhã, abre a banca e começa a acomodar os inúmeros brinquedos e ursos de pelúcia que vende. Este processo demora cerca de três horas; às vezes, dependendo das interrupções que o vendedor tem, estende-se até o meio dia.

Durante a manhã o movimento é pequeno, aumentando durante a tarde e anoitecer. Ângela, como todos os camelôs, passa o dia ao lado da banca à espera de clientes. Sua distração, durante a longa jornada de trabalho, consiste em troca de risadas, deboches e piadas com os vizinhos de ponto. As refeições são feitas ali mesmo, quando algum conhecido leva o alimento. Caso contrário, é necessário negociar com o vizinho uma saída, uma fuga, para lanchar em algum restaurante por perto. Um dos hábitos mais comuns entre camelôs é tomar o "cafezinho". De tempo em tempo, passa um vendedor ambulante de café e todos compram "fiado".

Entre o tempo ao lado da banca, uma conversa com o vizinho, um amigo que visita, uma venda que se realiza, o dia passa e muda a fisionomia dessa área do Centro. A região, após às 19 horas, fica repleta de ambulantes e de vendedores de alimento. Além disso, fecha-se o comércio formal. O dia de um camelô termina por volta das 22 horas. O movimento começa a diminuir na Praça, e as bancas começam a ser desmontadas e fechadas. Os vendedores vão embora, contentes ou decepcionados com o que conseguiram vender. Todo esse processo foge de uma lógica do trabalho convencional. Tudo se passa na 
rua, o trabalho e a vida pessoal se confundem numa jornada de até 15 horas diárias.

Aos sábados e domingos, os camelôs também trabalham. Nesses dias, o Centro é muito diferente dos dias de semana: sem os trabalhadores das grandes empresas e setores administrativos, ele é palco de uma verdadeira festa das camadas populares de Porto Alegre. Todas as ruas, sem exceção, ficam sem espaço devido aos ambulantes que invadem a região. Se durante a semana o camelódromo parece grande, aos finais de semana, ele fica minúsculo (pelo menos aos meus olhos). O interessante nestes dias é o tom festivo que se estabelece. Os vendedores de $c d s$ colocam músicas num volume muito alto, as vendedoras dançam o Funk e o Pagode que toca. Além disso, dezenas de vendedores de churrasquinho ficam às voltas, é não é exagero dizer que o Centro fica coberto por uma nuvem cinza da fumaça. O cheiro de comida e a música tomam conta das proximidades da Praça XV, do Mercado Público e da Praça Parobé. Pessoas de toda a cidade vai para lá, uns para visitarem, outros para passearem. Nos dias de "passe livre" nos ônibus (finais de semana e feriados) este ambiente se agita ainda mais.

\section{b) A re-invenção do espaço público}

A vivência cotidiana dos camelôs de até 15 horas diárias na rua faz com que os papéis do espaço público e do privado se invertam. Na contemporaneidade, a idéia de rua está associada ao público, em contraposição ao espaço da casa, que reserva as relações da vida privada e da intimidade. Essa peculiaridade da sociedade ocidental é apontada por Ariès (1981:253) quando analisa modificações das relações familiares nos espaços públicos e privados na passagem da Idade Média para a Moderna. Ou seja, as relações íntimas e familiares se restringiram ao espaço da casa, surgindo, em decorrência, códigos de conduta de civilidade tanto para adultos quanto para as crianças, no que concerne ao comportamento nos espaços públicos .

Para a historiadora Pesavento (1992:08), esse tipo de transformação atingiu o cenário urbano de Porto Alegre a partir do século XIX e correspondeu a uma mudança global, marcada pela transformação do capitalismo, qual seja o nascimento da ordem burguesa e a expansão progressiva de seu corolário de crenças, valores e idéias. Neste contexto, as cidades (como Porto Alegre) começaram a se industrializar e a se modernizar, de modo que passam a ser o centro dos acontecimentos da vida nacional, "é o lugar onde 
tudo acontece". Assim, uma das conseqüências mais marcantes desse processo é a transformação dos papéis da casa e da rua, que se tornaram esferas separadas e até opostas. A casa passou a ser o local das trocas íntimas, da família, do privado, em contraposição à rua, que passou a ser o local do público, das trocas impessoais, das multidões e do anonimato.

Para os camelôs, a lógica da modernidade e do individualismo (que se estabeleceu na sociedade ocidental moderna no século XVIII e em Porto Alegre na passagem do século XIX) não corresponde ao seus estilos de vida e visões de mundo. A rua continua sendo o local onde tudo acontece. Para eles, cada banca e cada entorno simbolizam pequenas casas. No interior delas, encontramos comida, espelhos, almofadas, escovas de cabelo e de dentes, etc. Por exemplo, Léia costuma se arrumar e se maquiar ao lado da banca. Sentada, olhando firme para um espelho, ela não percebe as centenas de pessoas que passavam ao seu lado. Age como se estivesse num lugar muito reservado.

Outro exemplo sobre este tipo de ocupação do espaço público, refere-se à maneira como sou recebida quando vou à banca de Ângela, ele age como se estivesse na sua própria casa: convida-me para sentar, oferece-me café e diz: “fica à vontade”. Em volta de sua banca ela possui cadeiras de madeira, ventilador e, para completar, um tapete estampado ou um carpete sobre o cimento. Eu brinco com ela: “como estás chique!” E ela responde: “é para poder viver aqui”. Numa ocasião de entrevista ela complementa:

\footnotetext{
"Aqui faz parte da vida da gente, se não a gente não tem como viver aqui das sete horas da manhã, às dez da noite. Então tu vive aqui, é a tua casa. Tem que fazer um círculo de família com eles [vizinhos] que tu não faz em casa, em casa tu vai para a casa e dorme, aqui o dia inteiro... porque a gente tem que almoçar aqui do ladinho da banca, ou acompanhada dos clientes mesmo, se sentar numa cadeira, num banquinho. E ficamos ao lado da banca porque não tem como deixar ela sozinha”
}

Na fala de Ângela, a família é a da rua e não a da casa. Dentro do camelódromo, além da família convencional, existe a família da rua, constituída entre vizinhos de confiança e convivência diária. Os problemas de relacionamento e os momentos bons compartilhados ocorrem na rua, dentro do quadro de suas vivências cotidianas. Outro ponto levantado por Ângela remete às necessidades básicas de comer, ir ao banheiro e descansar. Esses atos, considerados pela nossa sociedade como momentos extremamente íntimos e 
privados, ocorrem em pleno espaço público. Comer, dormir e descansar, atos corriqueiros, ocorrem ao lado da banca. Para ir ao banheiro, deve-se negociar com algum vizinho que fica cuidando da banca enquanto o vendedor vai rapidamente a um banheiro público.

Em especial a maneira como seu Anibal e seus vizinhos de banca - situados na margem do camelódromo em frente ao chalé da Praça XV de Novembro - apropriam-se da rua é surpreendente: afastam suas cadeiras das bancas e colocam-nas nas escadas da Praça XV. Todos os seus vizinhos, lado a lado, ficam neste local o dia inteiro lendo jornais, descansando e conversando. Entre eles passam milhares de pessoas por dia e nem reparam, agem como se estivessem nos pátios de suas próprias casas.

Sob este ângulo, posso afirmar que as relações afetivas também acontecem na rua. É muito comum nascer flertes, namoros e até casamentos entre eles. Os relacionamentos, geralmente entre os mais jovens, começam com olhares e brincadeiras entre uma venda e outra. A rua é palco, portanto, de paixões que se fazem e se desfazem. Até mesmo as relações sexuais seguem a lógica de que a rua é a casa. Depois de conhecer melhor alguns vendedores, alguns camelôs contaram-me as negociações e estratégias que eles desenvolveram para, como eles mesmo dizem, "darem uma escapadinha". Assim, muitas vezes, o ato sexual - convencionado por nossa sociedade como um dos atos mais privados acontece num cenário da vida pública. ${ }^{12} 13$

Percebi, enfim, ao longo do meu trabalho de campo, que uma das especificidades do grupo centra-se no fato de que muitas concepções sobre intimidade e privacidade e saúde estão relacionadas ao público e à rua, ao contrário do resto da sociedade, que relaciona estas noções ao ambiente privado. Portanto, temos ao mesmo tempo, a privatização do espaço público e a publitização do vida dos camelôs que, de forma criativa, ressignificam os sentidos dado à rua. Não é de estranhar o pedido de alguns professores durante uma palestra que ministrei sobre a presente pesquisa: "Por favor, não fala para as crianças e adolescentes que eles fazem sexo na rua!”... Percebe-se, nesta fala, uma concepção moral interiorizada sobre o papel da rua. Ou seja, falar sobre "o sexo na rua" para os alunos da escola, seria como falar de uma promiscuidade, de algo que se deve calar. 


\section{c) Os males da rua:}

A maior queixa dos camelôs quanto aos problemas de saúde é a vulnerabilidade de seus corpos diante do constante contato com a chuva, o sol, o vento, o frio e o calor. O fato de estarem na rua faz com que estejam expostos às variações térmicas e climáticas e se tornem propensos a gripes e resfriados.

O período de chuva do rigoroso inverno gaúcho é percebido pelos camelôs como verdadeiro drama. Os agasalhos não esquentam o suficiente, e a chuva acaba atingindo a todos inevitavelmente. Deste modo, os dias de calor e muito sol também são prejudiciais, alterando a pressão sangüínea de muitos vendedores, principalmente os mais velhos.

Os vendedores que estão há muitos anos na profissão são os mais atingidos pelos malefícios à saúde. As trajetórias individuais dos camelôs demonstram que eles estão nesta atividade há 3 ou 4 décadas. Portanto, iniciaram na faixa etária dos 20 a 30 anos. Entretanto atualmente percebo que a vida na rua começa cada vez mais cedo com o trabalho de adolescentes e crianças que já encaminharam seus futuros. Um fato que me chamou a atenção é uma criança de apenas 13 dias que já passava o dia na rua junto com seus pais camelôs. A menina desde o seu segundo dia de vida já ficava sobre um berço improvisado ao lado da banca , exposta ao sol e a uma temperatura de 35 graus. Percebe-se, neste episódio, uma concepção atípica diante do padrão de normalidade difundidos por políticas médicas e higienistas $^{14}$ sobre os cuidados "super- protetores" com récem- nascidos, interiorizados por camadas médias urbanas.

Estar enfermo entre os camelôs é bastante comum. Entretanto, há uma concepção difundida entre eles referente às alternativas de cura para doenças. Assim, enquanto a saúde fragilizada é um estado constante e inevitável, o tratamento passa a ser banalizado, ou seja, há uma noção de que a doença é tão presente entre eles que não há nada para fazer, adoecer passa a ser algo inevitável. Esse fato pode ser comparado com o estudo de Knauth, Victora e Leal (1998) sobre uma comunidade em que o risco da AIDS era tão presente na vida das pessoas que as alternativas de precaução passavam a ser banalizadas também. No caso dos camelôs, assim como a doença é inevitável, a permanência com a mesma e a acomodação diante do estado também passam a ser inevitáveis.

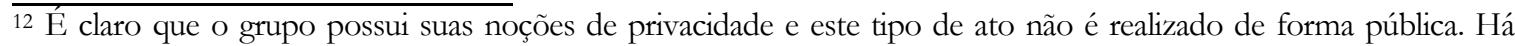
todo um jogo para ocupar locais que lhes reservem intimidade, tais como banheiros e becos.

13 As trocas íntimas (beijos, abraços e relações sexuais) nos espaços públicos acontecem geralmente com os vendedores mais jovens ou ambulantes.
} 
O discurso de inevitabilidade também se encontra nos vendedores mais antigos, no momento em que todos eles dizem que já não têm idade para fazer outra coisa na vida; não há mais nada a fazer além de se acomodar. Nesse sentido, percebi que todos os vendedores não procuram a assistência médica para nenhum de seus problemas, nem para os mais graves. A busca por ajuda médica acontece somente em casos extremos como no caso da vendedora Léia, que teve um enfarte no meio da rua, ou como Dona Diva, que um dia acordou e não consegui mais caminhar por causa de seu problema de joelho.

Os camelôs dizem que não vão ao médico porque não podem deixar de trabalhar (esta fala é comum entre todos, dizendo que a banca é único sustento e depende totalmente deles). Entretanto, percebo que, para a realização de outras atividades, sempre há uma maneira de deixar a banca com algum ajudante ou familiar. A recusa pela alternativa médica parece estar muito mais ligada a um estilo de vida e visão de mundo (de inevitabilidade e banalização da doença) do que propriamente a uma dificuldade do trabalho cotidiano.

Vejamos alguns casos específicos, retirados de minhas entrevistas e diários de campo. Seu Anibal, que trabalha há 30 anos como camelô, sofre de problemas na coluna, nos rins e reumatismo. Para a ele, a busca pela cura acontece somente em casos de muita dor; quando ele não suporta mais, recorre a um farmacêutico amigo que receita os remédios.

“(...) as dificuldades são muitas, para ir no médico tu leva ao último ponto, tu não pode deixar a banca sozinha. Quando eu fico doente eu vou à farmácia, tem uma amiga, tem pessoas que são amigas da gente, amigas minhas que trabalharam comigo quando eu tinha banca na Voluntários da Pátria. Daí, no final de semana eu vou ali na Farmácia da Voluntários, são gente finíssima, eu peço o remédio, eles me dão um antibiótico, um isso, um aquilo (...) Tu fica na rua, arruma problema de rim, minha filha tem problema de rim, eu tenho problema de rim, só de trabalhar aqui na hora da chuva e do sol. Temporal, meio d'água... É muito ruim o calorão. É coluna, é rim, é reumatismo. Isso aí todo mundo tem, é daqui mesmo. Mas vale a pena, é melhor do que trabalhar como empregado."

Assim como Anibal, Dona Diva também sofre de problemas de saúde, tendo problemas cardíacos e nas articulações. A ida ao médico para ela acontece somente quando não consegue mais trabalhar. Ela atribui a doença ao trabalho sacrificado do dia-a-dia, que a impede de sair de perto da banca.

14 Sobre esse tema, Donzelot (1983). 


\begin{abstract}
"A gente conseguindo estar caminhando e estar de pé, a gente vai trabalhar porque a gente é obrigado a trabalhar mais senão fosse preciso, se tivesse outro meio, a gente ficava em casa quando doente. (...) Eu estou cheia de... (pede para desligar o gravador) ... a gente tem muita doença aqui. Porque a gente pega sol, pega, chuva, pega vento. Eu estou assim por isso, eu acho que daqui um ano, dois eu nem vou poder caminhar por causa do problema que eu peguei no joelho, daqui mesmo. A rótula do joelho inchou de tanto ficar de pé. Eu tinha bastante saúde. Agora eu vou dizer uma coisa para ti, para eu ir no médico só quando eu não puder caminhar. Porque tem que trabalhar. De tanta incomodação, eu tenho problema de angina."
\end{abstract}

A camelô Léia há dois anos teve um enfarte na época de Natal. As narrativas dela sempre valorizam o sofrimento e as dificuldades da vida da rua. Seus olhos são cansados e profundos e a pele, envelhecida por causa do sol e do vento. Na época das festas do final do ano de 2000, ela, ao ver que não havia conseguido vender o suficiente para promover uma ceia natalina para seus filhos, entrou em desespero e sofreu um enfarte. Foi levada por camelôs ao Hospital de Pronto Socorro e até hoje precisa manter-se tomando remédios extremamente caros. Em agosto de 2002, perguntei como ela estava do coração e então respondeu-me que não tinha dinheiro para comprar os remédios, que era impossível trabalhando, parar de fumar e de tomar cafezinho.

Na mesma faixa etária de Léia, a vendedora Sarah (29 anos), engravidou indesejadamente. A alternativa foi tomar o remédio abortivo Citotec, vendido no camelódromo. Por causa disso, ela teve infecções e atualmente está com nódulos no útero que a impede de fazer o trabalho de força que ela costuma realizar. Perguntei se ela iria ao médico e assim me respondeu: "só daqui um ano, quando eu tirar férias". Contava-me que estava muito mal e que sabia que estava com nódulos enormes. Gesticulava com os dedos dizendo: "São assim óh... desse tamanho, é daqueles que tem cabelos e dentes".

No caso de Sarah, o curioso é que ela possui um funcionário e o marido que podem substituí-la. Além disso, muitas vezes em que eu estive lá, ela tinha saído para descansar, comer e ir ao cabelereiro arrumar o penteado que a chuva tinha estragado. Portanto, percebese que a recusa pelo tratamento médico segue princípios mais ligados ao estilo de vida e visões de mundo do grupo do que por dificuldades de tempo e dinheiro. O trabalho e sofrimento são valorizados de tal modo que a doença parece ser algo que eles devem carregar 
com enfado, correspondendo a um ethos caracterizado pelo sofrimento físico e pelo martírio enquanto "Valor-Trabalho"15 da identidade do camelô.

\begin{tabular}{|l|}
\hline \\
\hline Relação de doenças causadas pela vida na rua \\
\hline As mais simples: \\
\hline Gripe e resfriados \\
\hline Stress \\
\hline Alterações na pressão sangüínea \\
\hline Problemas de pele \\
\hline As mais graves: \\
\hline Doenças do coração (enfarte e angina) \\
\hline Doenças na coluna vertebral e articulações (joelhos) \\
\hline Doenças de pulmão \\
\hline
\end{tabular}

Problemas de Rins

Para Victora e Knauth (2000:21), a saúde e a doença não estão relacionadas somente à sua definição biomédica, são objetos de representações e tratamentos específicos em cada cultura. "Independente do fenômeno biológico, a doença só pode ser pensada como tal dentro de um sistema simbólico que lhe define, confere-lhe sentido e estabelece os tratamentos a serem adotados. Além disso, a doença, além de ser um acontecimento individual, mobiliza um conjunto de relações sociais". As doenças dos camelôs são frutos de suas condições econômicas, sociais e culturais. É no contexto simbólico das relações que a vida da rua estabelece que as doenças assumem sentido.

\footnotetext{
15 Para Duarte (1986:43) o valor é algum elemento simbólico que engloba e opõem outros. Valor-Trabalho é um dos níveis situacionais da construção da identidade social das classes trabalhadoras urbanas.
} 
Percebe-se, nos casos citados acima, que os problemas de saúde estão presentes em todos os vendedores e são oriundos de uma condição social. Entretanto, o tratamento das doenças está ligado totalmente ao plano simbólico, no que concerne às visões de mundo e estilos de vida daquele grupo, seja por uma banalização da doença, seja, por uma valorização do trabalho e do sofrimento. Assim, por mais que a dor seja sentida individualmente, ela é compartilhada e interpretada coletivamente dentro do camelódromo.

Nesse sentido, a morte segue os mesmos princípios. Se não há uma preocupação com a prevenção de doenças e nem mesmo com o tratamento das mesmas, logicamente não há uma preocupação com a morte. Segundo a vendedora Maria, que trabalha há 45 anos no camelódromo, os camelôs não pensam em nenhum tipo de precaução para a morte. Devido ao fato de ela ser uma das camelôs mais antigas, já presenciou muitos de seus amigos morrerem e deixarem as famílias sem nenhum recurso financeiro. Além disso, "o pessoal aqui tem que fazer uma vaquinha para comprar o caixão do morto e poder fazer um enterro". Portanto, assim como a doença, a morte obedece aos mesmos critérios. Afinal, os camelôs acham que ficar doente é algo inevitável, e não há nada para fazer; ao mesmo tempo, quando dizem que não podem ficar doentes de jeito nenhum, estão negando seus estados de enfermidade . Logo, a morte não é algo pensado dentro do quadro de possibilidades do grupo.

\section{d) Artes de fazer: sabedorias de um camelô.}

Para ser um autêntico camelô é necessário dominar uma série de técnicas que são aprendidas no cotidiano. Para os vendedores, não é qualquer um que pode exercer a profissão. Segundo afirma seu Ney, que trabalha há 40 anos nesta profissão: "A pessoa que não tem estudo, mas tem inteligência, pode se dar bem aqui, mas tem que ter inteligência." A filha dele, a Ângela, interpreta o trabalho da mesma maneira, salientando que o camelô é uma pessoa dotada de qualidades especiais:

(...) Tu vê , tem gente que não consegue trabalhar aqui, a pessoa para trabalhar aqui tem que ter um dom especial, tem que ter um $Q I$ mais, mais... porque tem gente que vem trabalhar aqui para servir tipo um balconista e não se adapta... Colocação de plástico quando chove, uma joaninha, sobe e desce do banco... é difícil trabalhar aqui." 
Este tipo de conhecimento, que De Certeau (2002) chama de artes do fazer, constitui-se como um repertório de ações e práticas que organizam e dotam de sentido o ofício de um camelô. Ressalto aqui dois pontos: as técnicas de vendas e as técnicas da banca.

\section{Técnicas de vendas:}

Para Mauss (1974) o aprendizado da técnica corporal consiste em uma imitação prestigiosa, imita-se aquele que gera respeito, aquele com quem se identifica. Para realizar a venda, todos os camelôs possuem uma série de hábitos e segredos que é a sabedoria de cada um e deve ser repassada aos seus filhos ou funcionário fiel.

Anibal, aliviado, fala de seus 4 filhos que já são camelôs: "Passei isso para todos os meus filhos, graças a Deus, graças a Deus...”

Para os camelôs, os clientes se acostumam com o vendedor e com a maneira como ele atende. Por isso, eles acreditam que não podem deixar a banca, pois só eles sabem atender. As performances de venda consistem no bom atendimento. É uma atuação que parte sempre do vendedor para o freguês. Se a venda acontecer, é devido ao sucesso do camelô; caso contrário, é culpa do cliente.

Em um diálogo com seu Anibal, eu lhe perguntava como se agrada um cliente:

"Desde o pequenininho de 10 anos já tem toda uma técnica de venda, já sabe conversar com um freguês, já sabe agradar um freguês, fazer a venda....há!? Se agrada um freguês tu conversando com ele, puxando um assunto com ele, puxa um monte de assunto com ele. Tu vai levando, tu vai levando, vai falando com ele... ele ai te perguntando sobre o negócio que tá comprando e tu vai conversando, vai conversando e até engatinhar que o negócio seja feito [risos] é tu tem que saber, né? Se tu ficar parado perto do freguês tu não vende. Ah! Tu coloca a mercadoria na mão dele para intimidar, né?”

Partindo das observações de campo, realizei o seguinte levantamento sobre os dois momentos rituais em que a venda se divide: 
Chamamento do cliente. Para atrair um comprador, é preciso dominar a técnica vocal de anunciar o produto (Ex. "Pode chegar, amiga", "É baratinho, pode chegar", "Cd barato, cd barato"). Essas falas são sempre repetidas e possuem um tom de voz específico. Além disso, é preciso ter uma boa banca com os produtos bem visíveis e bem arrumados. Alguns vendedores acham que devem estar bem arrumados para o cliente não ficar com medo de chegar à banca.

Atendimento. Depois de o cliente ter se aproximado, o vendedor precisa agir com simpatia e cordialidade, agilidade, manter uma conversa, evitar o silêncio, colocar o objeto na mão do cliente.

\section{Montagem da lona de proteção:}

Já os trabalhos de maiores dificuldades para os camelôs exigem qualificações de certos domínios específicos. Seja no equilíbrio e na concentração necessária para montar e desmontar uma banca, seja no trabalho de força para armar e desarmar a lona de proteção que necessitam colocar quando ameaça chover. A montagem da lona de proteção da chuva é um trabalho extremamente pesado, exigindo que os camelôs se dividam entre aqueles que amarrarão cordas no poste e aqueles que montarão uma sustentação vinda do chão. A força é realizada igualmente entre homens e mulheres.

Em julho de 2002, fui a campo e percebi que a lona de proteção estava muito maior. O vendedor Pio contou-me que cada camelô do lado dele contribuiu com R\$ 2,50 para comprarem um fio de aço que foi amarrado em torno dos postes próximos às suas bancas. Deste modo as cordas da lona foram amarrados neste fio, ficaram firmes e não levantaram mais. Essa "invenção do cotidiano" foi uma solução encontrada depois de anos sofrendo os prejuízos que a água da chuva provoca. A lona foi tão aprimorada que é difícil de entender como eles a instalam tão rapidamente. Porém, esta solução é temporária, visto que é ilegal e já está fazendo com que os postes da Praça XV fiquem inclinados. Além disso, Pio ressalta, 
"não vai durar muito tempo, os vendedores do lado de lá estão morrendo de inveja". Trata-se de uma grande obra, uma verdadeira engenharia do homem da rua. Somente um camelô, que acumula saberes da vida cotidiana, conseguiria fazer isto. Eu mesma quase "voei" uma vez em que eles me pediram que ajudasse, segurando firme as cordas.

A Secretaria Municipal de Indústria e Comércio só permite a lona de proteção em caso de chuva. Portanto, eles só podem montá-la quando ameaçar tempo ruim. Assim, o trabalho é realizado em aproximadamente 10 minutos. A maioria das vezes a chuva chega antes, fazendo com que os camelôs fiquem todos molhados e estrague boa parte das mercadorias. A impossibilidade de sair da banca faz com que os camelôs fiquem com a roupa e sapatos úmidos durante todo o dia, ocasionando problemas de saúde.

\section{Das artes do bricoleur: a banca.}

O ponto e a banca são quase tudo na vida de um camelô. Tudo se passa em torno deles. Por isso, procuro dar a eles uma atenção especial nesta análise, pois pode revelar muitas coisas para a compreensão do grupo social.

A montagem da banca aproxima-se ao trabalho de um bricoleur. Para Lévi-Strauss (1997:32), o bricoleur se utiliza de recursos limitados (o que dispõe à mão) e não possui um projeto de sua obra. Porém pode alcançar resultados brilhantes. O camelô possui um número determinado de mercadorias com as quais tem que fazer um arranjo. Cada dia é um arranjo novo com o mesmo repertório de peças. O resultado final é uma harmonia de cores e formas obtidas através de um conhecimento prático.

Muitas bancas alcançam tais resultados. Seja em seu sentido prático, seja na sua contemplação estética. Cada mercadoria é pensada e arquitetada a fim de valorizar e tornar os objetos bem visíveis aos olhos do cliente. DeCerteau (2002: 42), em relação aos fazeres cotidianos, enfatiza: "Essas práticas colocam em jogo um ratio 'popular', uma maneira de pensar investida numa maneira de agir, uma arte de combinar indissociável de uma arte de utilizar".

Colocar os objetos sobre a banca pode levar até três horas. Nesses momentos, os vendedores pedem que não sejam atrapalhados. Afinal, precisam de equilíbrio e 
concentração. São artes e segredos de que os vendedores se orgulham. As bancas, cada uma de seu jeito, demonstram a imagem de seu dono. Por exemplo, Ângela - uma vendedora que está sempre feliz e sempre vê o lado positivo da vida - possui uma banca que esbanja cores. Léia - que sempre lamenta as dificuldades da vida na rua - possui uma banca opaca, na qual se sobressai o tom cinza Fato este comum na organização das grandes feiras do Terceiro Mundo, pois Lévi-Strauss (1996:97), ao analisá-las, nos anos 30, anunciava: "No Brasil, como na Bolívia ou no Paraguai, as grandes feiras e mercados, ocasiões da vida coletiva, evidenciam um regime de produção ainda individual; cada tabuleiro reflete a originalidade de seu titular. (...) Cada vitrine, que são todas humildes obras de artes, expressam uma diversidade de gostos e de atividades, um equilíbrio específico para cada uma delas, que depõem em favor da liberdade preservada por todos...".

Todas as bancas têm a capacidade de abarcar dezenas de objetos de maneira extraordinária. Muitas vezes, parecia-me incompreensível como aqueles vendedores conseguiam arrumar tanta coisa. Olham, olham mais um pouco, e acabam achando mais um canto para um objeto. Assim, cada banca assume a forma que seu dono quiser, e durante horas o vendedor coloca objeto por objeto com extremo cuidado. Parecendo milagre ou mágica, centenas de mercadorias são colocadas em um espaço muito pequeno. Um leigo, ao olhar as mercadorias arrumadas com tanta precisão, diria que, retirar uma só, significaria desmontar e derrubar todo o resto. São quatro ou cinco sacolas que devem ser esvaziadas para que tudo caiba num espaço de um metro quadrado. É uma negociação por centímetros, e sempre quando eu pensava que tinha acabado a arrumação, que não cabia mais nada, ressurgia mais um objeto que era colocado com uma profunda concentração nos olhos fixos do vendedor, olhando para as bases da banca. Poder-se-ia denominar esta parte da rotina de mágica, ou até mesmo de escultura.

Durante uma ida a campo, pedi a um vendedor para fotografar sua banca

"O seu Luís não parava de arrumar a banca para a hora da foto, colocava e retirava um óculos, pois não sabia ao certo se estava combinando, acabou tirando, me mostrando um senso estético muito rigoroso e aguçado. E neste embalo, todos os vizinhos vieram opinar, contavam-me como montavam suas bancas e que elas eram as mais arrumadas, 
'fulano não cuida da dele, eu cuido, até coloquei mais um andar'. E assim iam, pedindo para fotografar suas bancas, quando vi estava tirando fotos de todas. Afinal, como eu diria que a banca deles- que dava sustento às suas respectivas famílias, que ficava ao seu lado durante 15 horas ao dia, que arrumavam como se fosse um enfeite, ou seja, que era tudo para eles simplesmente, não daria uma boa foto?!"

Assim, a banca é uma arte. Nenhum vendedor ousaria a colocar de qualquer maneira os objetos sobre a banca. E até mesmo os mais pobres (os ambulantes) - aqueles que vendem um tomate apenas e algumas cabeças de alho sobre um papelão - colocam o tomate no canto direito inferior do quadrado, as cabeças de alho em fileira na linha de cima e , para completar o equilíbrio da forma, um pequeno monte de agrião no canto esquerdo inferior.

Já a banca de Ângela não só é a maior do camelódromo, como também a maior banca de Porto Alegre. Orgulha-se disso, montando durante horas os ursos de pelúcia que deverão ser vendidos ao longo do dia e, não contente com o pequeno espaço, montou um grande arco sobre a banca e nele pendura os maiores ursos que tem para vender, ela diz que é o "shopping" da Praça XV.

Tudo se pode encontrar numa banca de camelô. Desde miudezas até as últimas tecnologias. Porém tudo com um preço muito inferior comparado ao das grandes lojas dos shoppings centers. Observando o que é vendido e as pessoas que compram no camelódromo, percebi que lá acontece uma reinvenção do mundo globalizado pelos grupos populares. Ou seja, os camelôs pintam e moldam esse processo econômico e social conforme seus estilos de vida. Afinal, qualquer produto de última geração, lá pode ser encontrado. Todas as grandes marcas são falsificadas, pirateadas, imitadas, etc. São camisas, calças e casacos estampando grifes como Nike, Reebok, Calvin Clain, etc.

Segundo De Certeau (2002:40), os processo hegemônicos econômicos e culturais (que produzem linguagem) são interpretados conforme a criatividade popular dos consumidores. Ou seja, a produção de significados que a elite impõe, não indica de modo algum o que ela será para seus usuários. Para o autor, é necessário analisar a interpretação e a manipulação que os praticantes fazem da linguagem que recebem. Em relação aos camelôs, percebe-se que eles jogam com os mais profundos desejos de consumo das camadas populares, médias e altas. São atores sociais que manipulam popularmente as forças econômicas da globalização e assim, da mesma maneira que aceitam e reproduzem, 
mudam e reinventam este processo mostrando que nenhum processo social, por mais hegemônico que seja, domina plenamente os indivíduos. Enfim, tudo se vende, tudo se recria em um universo de múltiplas cores, de formas e linhas harmônicas. Arte da criação e manipulação do espaço, fruto da sabedoria da cultura popular.

\section{f) As Viagens: Aventuras e desventuras do contrabando.}

As histórias mais surpreendentes que ouvi dos camelôs referem-se às viagens realizadas em busca de mercadorias. Elas são narradas como verdadeiras aventuras, nas quais o ator principal faz de tudo para salvar suas compras.

Nem todos os camelôs viajam. Há uma divisão entre aqueles que vão para o Paraguai, para São Paulo e aqueles que compram nos atacados de Porto Alegre ou fabricam produtos em suas próprias casas. O preço do dólar e o perigo de ser pegado pela Receita Federal têm feito com que muitos vendedores optem por mercadorias nacionais. Entretanto, alguns anciãos e jovens aventureiros ainda preferem se arriscar viajando para o Paraguai.

Quando conheci Ângela e disse-lhe que gostaria de conhecer a vida de camelô, ela logo foi falando de seu pai, das histórias que ele tem para contar das viagens que realizou. Aos poucos, fui percebendo que as histórias eram dela também, pois as incorporava em sua narrativa. Na sua fala, a identidade social de camelô que ela assumia, perpassava pelos dramas vividos por seu pai.

Raramente trabalha uma pessoa apenas na banca. Na maioria das vezes, trata-se de um negócio familiar. Nas viagens para o Paraguai, geralmente são os homens que viajam e a mulher (esposa, filha, irmã, funcionária) fica cuidando da banca. As viagens se realizam uma a duas vezes por semana. O Ney (pai da Ângela) há trinta anos passa metade de sua vida no Paraguai e a outra metade em Porto Alegre.

Para Ângela, em sua concepção de mundo, a complexidade de conflitos que envolve os camelôs e Receita Federal se resolve da seguinte maneira:

“O Brasil tá muito perdido ainda, em termo de negócio, sabe, eles não sabem. Tinha que ter um Paraguai dentro de cada lugarzinho, tipo Porto Alegre, Santa Maria. Cada lugarzinho, Novo Hamburgo, São Leopoldo, tinha que ter tipo um Paraguaizinho. Assim, para as pessoas que tem pouco dinheiro poder comprar, para a gente não perder tanta mercadoria." 
Nesta visão de mundo, se cada lugar tivesse um "paraguaizinho", os camelôs não perderiam mais mercadorias nas viagens. Assim, o problema do contrabando, das "coisa ruim" que vêm do Paraguai, estaria resolvido. Neste momento, ela está negociando uma solução para um problema que perpassa toda a sua vida enquanto camelô.

\begin{abstract}
"Meu pai às vezes chega a ficar 15 a 20 horas escondido no meio do mato para não perder mercadoria. Dois mil real de mercadoria. Não é muito dinheiro mas tu traz alguma coisa para tu ganhar um dinheiro razoável de lucro. Então, imagina ficar 20 horas escondido no meio do mato... para uma pessoa que tem 60 anos, é um horror...isso é seguido, para não perder eles não obrigados a fazer isso. E quando tu não tem que fazer uma volta longa por outra cidade para poder chegar bem.. e o esgotamento nervoso, assalto. E é polícia corrupta que tem e quer levar a tua mercadoria para casa. Tem muita coisa ruim que vem do Paraguai que não precisava vir, como droga".
\end{abstract}

Entretanto, por mais que para Ângela estas histórias sejam verdadeiros problemas, é também motivo de orgulho o heroísmo a as façanhas que seu pai e seu marido realizam nas viagens. Quando fui apresentada para Ângelo, marido dela, ela logo me disse: "ele também tem histórias para contar. Conta, conta, Ângelo para ela as coisas que tu passou". Ele, então, falou-me que já foi preso junto com contrabandistas e que, por causa disso, conhece muito bem este "povo ruim". Além disso, contou-me dos prejuízos financeiros que teve quando a Polícia Federal retirou todas as mercadorias dele e da bravura como agiu enfrentando-os.

Seu Ney, em outra ocasião, acrescentava:

"Eu já viajei por todo o Brasil, Belo Horizonte, São Paulo, hoje, prefiro o Paraguai. Já trabalhei com meia, calçado, com tudo que é mercadoria. A viagem pode chegar com tudo, mas também pode chegar sem nada. Eu já comprei no Paraguai, vim, cheguei num restaurante, jantei, comprei um pão. Cheguei em casa só com o pão debaixo do braço. Sem nada, só com o pão. A Federal me tomou tudo, me deu cota zero." 
Ângela, complementando o relato do pai: "Já ficou dois dia na floresta escondido, dois dias fugindo da fiscalização". Enfim, não se pode pensar a vida de um camelô, sem olhar para as viagens que realizam. Para muitos vendedores, metade de suas vidas se realiza fora de Porto Alegre, buscando mercadorias para vender na banca. As dificuldades que enfrentam, nestas ocasiões, são motivos de orgulho e bravura e alimentam o imaginário dos camelô. Os significados deste estilo de vida não se encerram na banca, na rua. Ao contrário, os percursos, as viagens, as aventuras são trajetos necessários para aqueles que se identificam com este tipo de profissão.

\section{g) Humor \& Erotismo: das artes de dizer}

Desde o meu primeiro dia de pesquisa de campo, reparei uma das principais características dos camelôs: o humor e a malandragem. Durante o dia inteiro de trabalho eles passam brincando, fazendo piadas, colocando apelidos nos outros. As brincadeiras são constantes e ajudam a aliviar a dureza do trabalho da rua. Não há camelô que não brinque, ou que, pelo menos, não aceite a brincadeira. Trata-se de um traço simbólico do grupo que os vendedores aprendem a desenvolver na vida cotidiana.

As piadas são feitas para todos. Ninguém escapa de ser motivo de deboche. Brincase com os vizinhos, com os clientes e com os passantes. No início do trabalho de campo, ouvia inúmeras "cantadas" daqueles que não me conheciam. A minha presença feminina entre os jovens camelôs era motivo de inúmeras gozações entre eles. Todos queriam mostrar sua masculinidade dando-me elogios múltiplos. Esse tipo de brincadeira, "a cantada", é a mais comum entre os jovens, principalmente entre os vendedores de CDs. Não há nenhuma mulher que passe por ali e não escute algum tipo de galanteio.

"Mexer" com as mulheres que passam sinaliza uma disputa e uma afirmação da juventude e da masculinidade. A brincadeira entre homens possuí a mesma função. Brincase com o vizinho chamando-o de feio, elogia-se aquele que conseguiu fazer uma venda para uma mulher bonita, etc. Quanto a mim, nunca tive nenhum tipo de estranhamento em relação a isso. 
Ao contrário, sempre achei engraçado este tipo de atitude. Muitas vezes, quando eu pedia que conversassem comigo ou que fizessem uma foto, eles agiam com extrema gentileza, disfarçando que estavam falando de mim. No entanto, não escapavam dos colegas que, imediatamente, começavam a dizer: “Aí, heim?! Ganhou a guria...”. Entre as cantadas mais comuns, temos as "famosas" falas às mulheres que por lá transitam: "Prá ti é de graça", "Menina bonita não paga, mas também não leva", "Eu casava contigo", ou quando passa uma menina com sua mãe: “Aí, sogrona!”.

Sem exceção, todas as vezes em que fui fotografar os mais jovens, eles começavam a brigar entre eles, disputando a fotografia, empurrando-se sempre em tom de brincadeira. Uma vez, estava entre eles, conversando com um rapaz que me mostrava os CDs. Logo chegou outro vendedor e começaram a brigar, ofendendo-se e se tapeando. Eu fiquei apavorada, pensei em sair correndo. Porém fiquei imóvel, não demostrei nenhuma reação. Segundos após, olharam para mim e caíram na risada, estavam "brincando".

Naquele momento eles me testaram: se eu saísse correndo ou demonstrasse medo, teria perdido toda a credibilidade e seria motivo de risos por muito tempo. Esse tipo de atitude me revelou que eles estavam representando e ironizando a imagem de perigosos que a sociedade faz deles, estavam jogando com o estigma que recebem enquanto grupo considerado marginalizado, querendo testar o meu medo. Ao fingirem brigar, os jovens camelôs manipulavam os símbolos sociais e culturais atribuídos ao medo e ao perigo.

Logo após a Copa do Mundo do ano de 2002, fui ao camelódromo com o cineasta e antropólogo francês Jean Arlaud. Mostrei-lhe o ambiente e apresentei-lhe a Ângela e Pio. Eles nem quiseram saber quem ele era e já começaram a falar: "Brasil, futebol". A Ângela, vendo que ele não entendia português, desistiu do diálogo. O Pio continuou. Cada um falava uma coisa diferente e ninguém se entendia. Ele, aproveitando-se da situação, começou a falar para o francês: zidanou (referindo-se ao fracasso da França e do jogador francês Zidane na Copa do Mundo). Todos começaram a rir enquanto percebiam que Jean Arlaud não entendia o que eles falavam. 
Enfim, o humor é uma presença constante entre camelôs. Ele serve como uma afirmação individual da personalidade daquele que brinca. Além disso, trata-se de um aprendizado que foram adquirindo na vida cotidiana, no trabalho da rua. Saber fazer a piada e saber recebê-la é uma aprovação que as pessoas devem passar para serem aceitas e poderem conviver com o grupo. Trata-se de mais um traço que define a identidade social dos camelôs.

\section{Considerações finais}

O Centro Porto Alegre, desde os tempos mais remotos, sempre esteve repleto de vendedores de rua. A Praça XV de Novembro, ontem e hoje, abriga centenas desses trabalhadores que não abrem mão de sair lá, embora pude analisar que inúmeras tentativas se sucederam ao longo da história com esse objetivo.

Esse tipo de políticas públicas simbolizavam uma Porto Alegre que necessitava se tornar uma cidade moderna, correspondendo a um fenômeno global. Nasceu, progressivamente, idéias e valores morais sobre o espaço da rua e, por conseguinte, sociabilidades públicas pautadas pela postura individualista e impessoal. Dentro desse processo, os vendedores de rua por serem grupos populares, estarem situados no mercado informal e ocuparem o espaço público de forma peculiar, passaram a ser um grupo outsider (ELIAS, 2000), considerado fora de lugar.

Ao ler os jornais diariamente, hoje ainda encontramos um discurso de cunho moral, que respalda os lojistas e o poder local no que concerne à necessidade de retirar os trabalhadores de rua da região central da cidade. No entanto, o que percebemos é que são justamente as formas populares de ocupação do espaço que permanecem no tempo e no espaço.

Durante todo o desenvolvimento deste trabalho "me perguntei" e me perguntaram se os camelôs não eram frutos do desemprego, fenômeno estrutural e crescente na economia capitalista brasileira. Hoje, a resposta que tenho é que o trabalho de rua, embora penoso (por sua carga horária exagerada, males que causam à saúde, falta de seguridade social, etc.) é, também, um estilo de vida dos camelôs. As artimanhas com o cliente, as aventuras e 
desventuras das viagens, o humor, a tolerância para agüentar os dias em que se tem dinheiro para comer um mês e os dias em que não há nada para comer, são maneiras de viver que somente aqueles que permanecem na atividade conseguem desenvolver com primor.

Enquanto para mim, a rua era um lugar de passagem e de anonimato, para a visão de mundo dos camelôs, ela é um lugar de viver e construir seus mundos e suas histórias nas quais as fronteiras entre o público e o privado se diluem. Por fim, entendo que a presença de vendedores de rua no Centro de Porto Alegre é quase um "patrimônio" do bairro. As inúmeras tentativas de políticas públicas para a retirá-los de lá, acabaram sendo ineficazes frente à tradição deste tipo de ofício, que permanece nas ruas em suas formas coloridas e populares de ocupação do espaço da região central porto-alegrense.

Porto Alegre, 2003 


\section{Referencias}

ANTUNES, Ricardo. Os sentidos do Trabalho. São Paulo: Boitempo, 2000.

ARANTES, Antônio. Paisagens Paulistanas: Transformações da espaço público. São Paulo: Ed da UNICAMP, 2000.

ARIÈS, Philippe. História Social da Criança e da família. Rio de Janeiro: LTC, 1978.

BASTIDE, R. As técnicas de repouso e relaxamento. In: QUEIROZ, Roger Bastide. São Paulo: Ática, 1983.

BORBA, Sheila Villanova. Transformações recentes na área central de Porto Alegre. Apontamentos para uma discussão. In: Estudos Urbanos, Porto Alegre e seu Planejamento. Porto Alegre: Ed. Universidade, 1993.

DAMATTA, Roberto. O Ofício do etnólogo, ou Ter 'Antropological Blues' . In: Boletim do Museu Nacional, Rio de Janeiro, 1978.

DE CERTEAU, Michel. A invenção do cotidiano. Petrópolis: Vozes, 2002.

-------. A invenção do cotidiano II. Petrópolis: Vozes, 1996.

DONZELOT, Jaques. A Polícia das Famílias. Rio de Janeiro: Graal, 1983.

DUARTE, Luiz Fernando Dias. Da vida nervosa nas classes trabalhadoras urbanas. Rio de Janeiro: Zahar Ed., 1986.

DUMONT, Louis, Homo Hierarchicus. São Paulo: EDIUSP, 1992.

EKERT, C. e ROCHA, A.L.C. Etnografia de Rua: estudo de antropologia urbana. Porto Alegre, In: Série Ilunimuras, BIEV/IFCH, 2001.

ELIAS, Nobert. A sociedade dos Indivíduos. Rio de Janeiro: Jorge Zahar, 1990.

------. O Processo Civilizador. Rio de Janeiro: Jorge Zahar, 1994.

FONSECA, Cláudia. Família, Fofoca e Honra. Etnografia de relações de gênero e violência em grupos populares. Porto Alegre: Ed. Universidade/UFRGS, 2000.

FRANCO, Sérgio da Costa. Guia Histórico de Porto Alegre. Porto Alegre: Ed. Da Universidade, 1998.

GEERTZ, Clifford. A Interpretação das Culturas. Rio de Janeiro: TCL, 1989.

KNAUTH, D. VÍCTORA, C. LEAL, O. A Banalização da AIDS. In: Horizontes Antropológicos. N.9. Porto Alegre: PPGAS, 1998.

LÉVI-STRAUSS, Claude. Tristes trópicos. São Paulo: Companhia das Letras, 1996.

--------. O Pensamento Selvagem. Campinas: Papirus, 1997.

MALAGUTTI, Manoel Luiz. Crítica à Razão Informal. São Paulo: Boitempo, 2000.

MATOS, Maria Izilda Santos de Matos. Cotidiano e Cultura. Bauru: EDUSC, 2002.

MAUSS, Marcel. As técnicas corporais. In: Sociologia e Antropologia. São Paulo: EDUSP, 1974.

MONTEIRO, Charles. Porto Alegre, urbanização e modernidade: a construção social do espaço urbano. Porto Alegre: EDIPUCRS, 1995.

--------, Discurso Ideológico e Formas de Sociabilidade no Espaço Urbano. In: Anais da XII Reunião da Sociedade Brasileira de Pesquisa Histórica. Porto Alegre, 1992.

--------, Trabalho e Violência: Conflitos cotidianos nas classes populares de Porto Alegre. In: Anais da XIII Reunião da Sociedade Brasileira de Pesquisa Histórica. Porto Alegre, 1993. PESAVENTO, Sandra J. Memória Porto Alegre. Espaços e Vivências. Porto Alegre: Ed. Universidade/UFRGS, Prefeitura Municipal de Porto Alegre, 1991.

-------. O Espetáculo da Rua. Porto Alegre: Ed. Universidade/UFRGS, Prefeitura Municipal de Porto Alegre, 1992.

-------. De Escravo a Liberto, Um difícil caminho. Porto Alegre: Instituto Estadual do Livro, 1988.

VELHO, Gilberto. Individualismo, anonimato e violência na metrópole. In: Horizontes 
Antropológios, N. 13. IFCH/PPGAS-UFRGS, 2000.

-------. Individualismo e Cultura. Rio de Janeiro: Jorge Zahar Editor, 1997.

--------. Projeto e Metamorfose: antropologia das sociedades complexas. Rio de Janeiro: Jorge Zahar, 1999.

VÍCTORA, C. KNAUTH, D. HASSEM, M. Pesquisa Qualitativa em Saúde: Uma introdução ao tema. Porto Alegre: Tomo Editorial, 2000.

\section{COLEÇÕES, REVISTAS E JORNAIS:}

HISTÓRIA ILUSTRADA DE PORTO ALEGRE. Porto Alegre, 1997.

REVISTA DO GLOBO. Porto Alegre, 1944.

-------. Porto Alegre, 1958.

CORREIO DO POVO. Porto Alegre, Edições de 1999 a 2002.

ZERO HORA. Porto Alegre, Edições de1999 a 2000.

DIÁRIO GAÚCHO, Porto Alegre, Edições de 2000.

Acervo Banco de Imagens e Efeitos Visuais/Laboratório de Antropologia Social/PPGAS-

UFRGS. http://www.estacaoportoalegre.ufrgs.br

\section{ANEXO:}

Linha do Tempo: Ocupação do centro de Porto Alegre por vendedores de r ua

1730 - A cidade de Porto Alegre começou a ser ocupada, tardiamente em relação ao resto das capitais brasileiras. A região que atualmente constitui o centro da cidade era uma parte da Sesmaria de Jerônimo de Ornellas. Este donatário (mito fundador da cidade), no entanto, não possuía nenhuma relação afetiva com sua propriedade, de modo que, colonos e comerciantes ocuparam estas terras e por lá se instalaram. O objetivo de Ornellas era criar gado em sua propriedade e não fundar uma cidade, como o que acabou acontecendo. (Coleção História Ilustrada de Porto Alegre, 1997: 20)

1752 - Porto Alegre emergiu e cresceu graças ao comércio que começou a se instalar na região central a partir do século XVIII. Com a chegada dos açorianos Nessa data, intensificou-se este tipo de atividade, principalmente no Largo da Quitanda, atual Praça da Alfândega. No final deste século, este logradouro caracterizava-se pela forte presença de escambo e vendas de peixe, fazendo expandir o comércio da cidade.

1800 (+/-) - De acordo com os registros municipais da época, antes de receber os quitandeiros do Largo da Quitanda havia no local uma famosa casa de prostituição que se chamava "Casa Paraíso", que originou o popular nome "Praça Paraíso".

1815 - A Praça paraíso foi predestinada pelo poder público municipal, para receber a Praça do Peixe. "ponderando que por se achar encarregado da obra da nova Alfândega, precisava se fizesse retirar daquele lugar as quitandeiras e mais mercados, lembrando poderem passar para a Praça do Paraíso, destinada ao Mercado do Peixe"16.

1820 - Foi construído o prédio dos serviços alfandegários e, por isso, houve uma

pressão dos grandes negociantes ${ }^{17}$ locais para retirar as bancas do pequeno comércio da praça com o intuito de melhorar a ambiência e evitar o mau cheiro do seu entorno. Os governantes decidiram que os vendedores de rua seriam transferidos para a Praça Paraíso ( atual Praça XV de Novembro).

Deste modo, a Praça Paraíso consolidou-se, ainda sem alguma urbanização, recebendo quitandeiros, negociantes e moradores; e passou a ser o principal local de 
comércio de rua da cidade de Porto Alegre. Atividade esta que lá se desenvolve até os dias de hoje. A tradição de negociantes e vendedores de rua -bancas irregulares de peixes, frutas, muidezas, etc - nas redondezas da hoje Praça XV de Novembro - é tão antiga quanto a própria praça, ou melhor, este tipo de atividade foi fundante para a sua consolidação na cidade.

1844 - Foi construído um mercado na Praça Paraíso- o primeiro da cidade - devido ao espanto do presidente da província, Saturnino de Souza e Oliveira, de que Porto Alegre ainda não tinha um mercado estabelecido, "este fundamental instrumento da vida

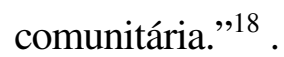

1969 - Inauguração do segundo mercado, construído também na Praça Paraíso, porém no alinhamento da Rua Voluntários da Pátria. (FRANCO, 1998: 270). Essa obra tinha o objetivo, de um lado, que Porto Alegre tivesse uma obra monumental como as das grandes cidades; de outro, acomodar melhor os comerciantes locais. Desde então, a Praça passou ser denominada “Conde D'Eu”.

1870 - Demolição do primeiro mercado. A partir desta data, começou um intenso processo e esforço de urbanização.

1880 - Até essa data a Praça era ponto de parada dos carreteiros.

1880- ( Final do século XIX)- Imaginário individualista, ideário de modernidade e moralização dos espaços públicos em Porto Alegre.

1889 - Com a Proclamação da República Praça recebeu o nome de "Praça XV de Novembro" (FRANCO,1998: 271).

1913 - Foi adicionado mais um andar ao Mercado, consolidando a sua forma que permanece até hoje.

1890 a 1924 - Consolidação da ordem burguesa na cidade com a renovação urbana e tecnológica que fizeram Porto Alegre viver "o sonho das cidades civilizadas européias". ${ }^{19}$ Neste período, de política higienista, os pobres são varridos do Centro, numa tentativa de impedir as sociabialidades populares, a promiscuidade e a prostituição. (1991:42).

1930-1950 - Auge do processo de industrialização brasileira. O cenário urbano de Porto Alegre muda radicalmente: os arranha-céus verticalizam a paisagem citadina, inicia-se a abertura de grandes avenidas que eram verdadeiras "cirurgias urbanas" (Pesanveto, 1991). As elites vivem o sonho da cidade moderna e civilizada na qual o centro, principalmente a Rua da Praia, é o palco do glamour com seus cafés, cinemas e matinês. Entretanto, é neste período que começa a inversão da proporção das populações rural e urbana. $\mathrm{O}$ número de habitantes das cidades se multiplicam com a explosão demográfica e com a acelerada migração do campo para as grandes metrópoles. Os que migram buscam trabalho e melhores condições de vida. Este grupo, aliado à numerosa população de origem africana pós-abolição, vão formar o grande contingente de pobres, população de baixa renda, que irão configurar o cenário urbano das grandes cidades brasileiras em busca de trabalho e de moradia. (Velho, 2000).

\footnotetext{
16 Ofício do Coronel Engenheiro, encarregado do Plano da Vila, João Batista Alves Porto. Em 08/11/1820.

17 Eram 57 ao todo. Entre os quais se destacam: casas de negócios, plantações de trigo, pequenos moinhos, criação de gado, sociedade em iates para navegar na Lagoa dos Patos. (História Ilustrada de Porto Alegre, 1997: 47).

18 Fala do Presidente da Província relatada pelo cronista Felicíssimo de Azevedo.
} 
"Por mais que o novo imaginário urbano se povoe das figuras de homens e mulheres bem vestidos, a flanar pelas ruas, existem outros personagens neste cenário urbano. A rua também é o meio de vida, onde cangueiros, biscateiros e vendedores ambulantes transitam diariamente, entrecruzando-se com carroceiros, amas-secas, motoristas, motorneiros e free-lancers de toda ordem. Neste sentido, a rua é do povo, onde se misturam operários, professores, caixeiros de loja, bancários, negociantes, e... porque não dizer, vagabundos, desocupados e larápios.

No plano das condições concretas da existência, ocorre um mercado formal e informal de trabalho, assim como se configuram também uma parcela da população que fica à margem deste mercado. No imaginário social as coisas se confundem, e as "classes trabalhadoras" são também "classes perigosas". Uma parcela destes elementos faz da rua o seu meio de vida e seu espaço de ação. [...]" (Pesavento, 1992: 64-65).

1958- Revista do Globo tem como manchete: "Comércio Ambulante, Pitoresco e Abusivo". Anunciando o crescente número de ambulantes no Centro de Porto Alegre.

1968- Legislação Municipal que legalizou ambulantes do entro de Porto Alegre.

1980 (década de) - O então Prefeito da cidade, João Antônio Dibb, apresentou um projeto complexo e ambicioso - "um centro mais humano". As administrações que se sucederam de Alceu Collares e Olívio Dutra também realizam planos para a melhoria do perímetro central. Nos últimos vinte anos, portanto, sucessivos projetos foram elaborados para "reerguer" o bairro. A Praça XV, por exemplo, foi alvo preferido dos planos de renovação [ou re-valorização, re-ordenamento, re-humanização] (Borba, 1993: 19 e 21).

1989- Prefeito Olívio Dutra, cumprindo promessa eleitoral, cadastra o universo de vendedores ambulantes de porto Alegre. Foi instituído o camelódromo da Praça XV de Novembro, da rua Marechal Floriano e Vigário José Inácio, e esses vendedores legalizados passaram a se chamar camelôs.

1998- Nasce o Projeto de Revitalização de Porto Alegre da continuidade desses projetos, numa parceria realizada entre a Prefeitura Municipal e o Sindicato dos Lojistas (SINDILOJAS) Neste pacto, o objetivo principal é, como denota o próprio nome do projeto, "revitalizar" o centro de Porto Alegre. Dentre as principais metas estabelecidas entre ambas as esferas, destacam-se a recuperação de prédios históricos, reurbanização das ruas e avenidas e o controle do comércio irregular presente na região. Cabendo ao poder público fiscalizar e controlar os ambulantes e camelôs, e aos lojistas financiar parte das obras de recuperação.

1998- A informalidade ultrapassa 50\% da população ocupada no Brasil. De 1994 1998, houve um crescimento de 5,2\%.

19 Entre as realizações mais marcantes temos a extinção de becos ( do Mijo, Pecados Mortais, do Leite, etc,) e abertura de ruas que passavam a receber nomes de personalidades notáveis. 


\begin{tabular}{|c|l|l|l|l|l|}
\hline Indicadores & 1994 & 1995 & 1996 & 1997 & 1998 \\
\hline $\begin{array}{c}\text { Trabalhadores sem } \\
\text { carteira assinada } \\
\text { conta própria (\%) }\end{array}$ & 47,40 & 48,20 & 49,90 & 50,40 & 50,70 \\
\hline
\end{tabular}

Fonte: “Uma economia de Justiça e Solidariedade”, 1999

2000- 1000 a 2000 vendedores ambulantes ilegais nas ruas entrais de Porto Alegre. 2000- Extinto o camelódromo da Rua Marechal Floriano por exigência dos lojistas. 2002- Anúncio para a inauguração de um shopping popular para camelôs e ambulantes trabalharem. 